\title{
El arte como función vital humana
}

\author{
Art as a vital human function
}

En su cotidiana interacción con el mundo, el hombre experimenta diversas emociones, las cuales no siempre puede manifestar abiertamente (represión), lo que da lugar a su introversión y, en consecuencia, a la aparición de tensión emocional y conflicto interior. Sin embargo, dichas emociones, en su incesante pugna por expresarse, logran, finalmente, aflorar en forma transaccional (sublimación), ya sea como formaciones de carácter beneficioso (actividad laboral, recreativa y creativa en general) o perjudicial (síntomas) (Freud-Jung)., ${ }^{1,2}$ Es por ello por lo que la extroversión creadora, con su escape a las restricciones de la realidad y su instalación de un espacio de libertad, constituye la fuente primordial de toda expresión artística, y que "arte" es cualquier acto u obra humana capaz de transmitir emociones (Tolstoi). ${ }^{3,4}$

Se entiende, entonces, que el arte es una necesidad vital del ser humano (Joyce), una ley de necesidad interior (Kandinsky), equiparable a la ventilación pulmonar, la circulación sanguínea, la reproducción y la nutrición, al ser la vía de escape saludable para los contenidos inefables de la mente (Donington). ${ }^{1,2,5-7}$

El artista logra expresar, mediante un lenguaje de imágenes (simbólico) producto de un juego combinatorio de sensaciones y fantasías, no solo sus propias emociones, sino también las de otros (espectadores), fenómeno conocido como contagio artístico (Tolstoi) y que se fundamenta en la eficacia simbólica ejercida por su obra (LeviStrauss). ${ }^{3,8}$ De esta manera, la emoción contenida (introvertida) encuentra una vía de expresión y la tensión interior se disipa tanto en el que crea (artista) como en el que disfruta de lo creado (espectador), ya que, en el espectador, la obra de arte funciona como portal de egreso para sus propias emociones. Por esta razón, el verdadero arte no necesita ser bello ni comprenderse, sino tan solo ser capaz de emocionar, es decir, de reflejar eficazmente el eterno-emocional humano (Wagner). ${ }^{3,4,6,7}$

En este sentido, la mismísima vida humana es una expresión artística: el Gran Arte, el cual engloba a todos los demás, incluidos tanto el arte convencional (pintura, escultura, música, literatura, poesía y cine) como la ciencia, dado que esta no es más que una forma de arte dirigido hacia el estudio analítico del mundo y la obtención de información verificable acerca de él. ${ }^{8,9}$

Otras funciones de la actividad artística son el facilitar la comunicación no verbal, la exploración cognitiva, la actividad lúdica, así como también ser fuente de placer. Precisamente por estas características y por estar siempre estructurado en torno a un orden rítmico es que se especula que las raíces biológicas del arte estarían en los juegos del cortejo animal; solo que, a diferencia de los animales, la energía que al Hombre le sobra para su vida biológica la canaliza en su vida cultural (simbólica), que es, justamente, en la cual despliega su arte (Spencer). ${ }^{10}$

Por este motivo, el genial escritor Fernando Pessoa dirá que la existencia del arte es la demostración más clara de que al Hombre la vida biológica no le alcanza. ${ }^{11}$

Concluimos, entonces, que la actividad artística, entendida como transmisión eficaz de emociones, es vital para el ser humano como vía de catarsis emocional, comunicación, conocimiento, juego y placer, tanto en el plano individual como colectivo.

Dr. Carlos G. Musso y Dra. Paula A. Enz Escuela de Medicina, Instituto Universitario del Hospital Italiano de Buenos Aires, Argentina.

http:/ / dx.doi.org/10.5546/aap.2016.292

\section{REFERENCIAS}

1. Freud S. Obras completas. Buenos Aires: El Ateneo; 2003.

2. Campbell J. Jung. New York: Penguin; 1976.

3. Tolstoi L. ¿Qué es el arte? Buenos Aires: El Ateneo; 1949.

4. Rodin A. El arte. Buenos Aires: El Ateneo; 1946.

5. Joyce S. Mi hermano James Joyce. Buenos Aires: Adriana Hidalgo; 2000.

6. Kandinsky V. Sobre lo espiritual en el arte. Buenos Aires: Need; 1999.

7. Jacob PW. Ricardo Wagner y su obra. Buenos Aires: Peuser; 1950.

8. Burguera Rozado J. El reencuentro con la eficacia simbólica. Big Fish. 2012. Versión Kindle.

9. Bunge M. Epistemología. Barcelona:Siglo Veintiuno; 2014.

10. Colombres A. Teoría transcultural del arte: hacia un pensamiento visual independiente. Buenos Aires: Del Sol; 2005.

11. Pessoa F. Máscaras y paradojas. Barcelona: Eldhasa; 1996. 